\section{The Impact of Inward FDI on the Growth of Advanced Ex-Ports in Central-Eastern European Region}

\author{
Agata Maria Gorniak \\ Kozminski University \\ $\Gamma$ \\ crosseg http://dx.doi.org/10.5755/j01.eis.1.14.27557
}

The main objective of the paper is to examine the potential factors which, according to the literature, may be impacting the structure of exports by allowing more exports from high and medium-high research and development intensive sectors. In the paper, particular emphasis is put on the foreign direct investment's role in export advancement. Apart from foreign direct investment inflows, the research examines the impact of trade openness, gross capital formation, gross domestic savings together with research and development and human capital related factors, on the phenomenon. The research group consists of eight Central Eastern European economies, accessed to the European Union in 2004. The statistical data utilized in the research is retrieved from commonly available statistical databases. In the study ordinary least squares panel data regression is applied. Three separate models are estimated for three varying time frames (within the years 2000 - 2018), depending on the variables data availability. Obtained results suggest a strong positive correlation between trade openness, investment factors (savings and capital formation) expressed in growth rates, and high and medium-high research and development intensive manufacturing exports. Even though foreign direct investment inflows are identified as statistically significant in two of the estimated models, the coefficient for the variable is low. The results are partially consistent with the literature on the topic. Trade openness and foreign direct investment inflows have both been identified as relevant factors in the previously conducted studies. In contrary to previous findings, the investment-related macroeconomic factors, such as gross domestic savings and gross capital formation appear as significant variables. Also, in the estimated models, factors related to research and development have no relevance.

KEYWORDS: Foreign Direct Investment, International Business, International Trade, Exports, High Technology Ex-ports.

Export of advanced technology products is one of the measures of international competitiveness of economies, therefore examining factors that may affect the development and changes in the commodity structure of export is of key importance in the context of building a globally competitive economy. Foreign direct investments (FDI) are commonly considered an opportunity for economic development for investment-accepting countries as due to their nature they may affect many aspects of the economy of a receiving country, including exports advancement. The strength and the direction of this correlation may vary between investment receiving countries.

The paper examines the correlation between export of products manufactured using high and medium - high research and development (R\&D) intensive technologies and the inflow of FDI per capita. Other variables which are used in the model are: gross domestic savings (GDS, as a percentage of gross domestic product (GDP)), gross capital formation (GCF, as a percentage of GDP), trade openness (as a ratio of imports and exports of goods and services to GDP), R\&D
EIS 14/2020

The Impact of Inward FDI on the Growth of Advanced Ex-Ports in Central-Eastern European Region

Submitted 06/2020

Accepted for publication 07/2020

Abstract

Introduction

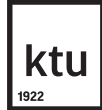

European Integration Studies No. 14 / 2020, pp. 137-145 doi.org/10.5755/j01.eis.1.14.27557 
spend, number of researchers per million, employment rate in high and medium high technology manufacturing sectors. The research group consists of eight economies of Central-Eastern Europe, whereas the studied timeframe covers the years 2000 - 2018, for which three different models with different time range are estimated.

In the first part of the paper, a literature review is presented, indicating channels of inflowing FDI impact on the export sophistication together with a brief presentation of other factors relevant for the study. The subsequent part of the paper provides a description of the data, model and its assumptions, and is followed by presentation of the study findings and conclusions. The results obtained from this simple panel estimation may complement the existing literature and lead to further research.

Literature review

\section{FDI as a factor impacting high - technology exports}

In the literature, FDI is often recognised as one of the factors that affect export. Apart from their possible effect on the intensity of export activity, thus contributing to changes in the volume and value, foreign investments may also lead to a development in export by means of changes in the export structure. This leads to a country becoming engaged in a circulation of more technologically advanced goods. The strength of this relationship and its occurrence is determined by many factors, such as the degree of economic development in the host country, the examined industry, the level of its technological advancement or the investor's country of origin.

Researchers indicate an overall positive correlation between inflowing investments and the diversification and advancement of the export structure of the host country. Nonetheless, there are different approaches and provisions made when examining this phenomenon, which result in some discrepancies between the results obtained or indicate a need for the specific criteria to be added to the conclusions. Presumably, two of the most common methods of research are those that divide the studies group by the country's level of development and the sectoral analyses. For example, correlations between FDI inflow and exports advancement can be observed only in relation to developing economies, additionally with a significant time lag of five years that is added to the model (Iwamoto, Nabeshima, 2012). In the sectoral study where the FDI inflows are included together with the FDI encouraging policies, it has been revealed that sectors determined as key for FDI promotion policies are able to generate more advanced exports. Since investments are often considered a technology carrier and an opportunity for domestic companies to learn, many countries use investment incentives, seeing FDI as a chance for a technological and economic development (Smarzynska Javorcik, 2004). Nevertheless, the positive effect of promoting FDI that resulted in the inflows increase is visible similarly only in the developing countries (Harding, Smarzynska Javorcik, 2011). In other studies, it has been proved that the correlation is higher in sectors originating from the host country, not originally focused on export where foreign investors may more effectively implement their knowledge and the applied technologies (Banga, 2006).

In the literature, there are mentioned two main ways in which FDI may impact export structure, namely, by direct export activity of foreign entities and by the spread of technologies and domestic companies learning from foreign investors (Iwamoto, Nabeshima, 2012).

\section{Export activity of foreign entities}

Foreign companies that transfer some or all of their production to the host country may affect its trade balance. In theory, foreign investors have an impact on the export structure and capabilities, being engaged in the exporting activities, therefore they may directly enhance the level of exported goods (Iwamoto, Nabeshima, 2012). Apart from changes in the export volume and val- 
ue, value added created in the recipient country is also significant. Foreign investors' activity may give a misleading impression of the level of technological advancement of exported products, specifically in a short time, export structure may not reflect resources and level of knowledge of domestic production. The reason for this phenomenon lies in the nature of FDI, which serve for fragmenting production process and transferring a part of it abroad, thus reducing the costs of manufacturing final products. Therefore, it may happen, that in the less developed economies, some advanced technology, semi - finished products, are imported, and subsequently exported after some basic industrial treatment. As a result, exported items are far more technologically advanced than indicated by the potential and the level of development of the FDI host country (Van Assche, Gangnes, 2007; Xu, 2010; Zhu, Fu, 2013).

\section{Spread of technologies and acquisition of knowledge by domestic companies}

In the literature, FDI is commonly considered one of the important factors that make diffusion of knowledge and technology possible, which has been proven mostly by the microeconomic studies (Keller, 2004). There are yet many studies related to the spread of knowledge and technology by FDI which differ in their assumptions and approach (for example firm-level, sectoral or cross-country and global analyses). In addition, the strength of this relationship is determined by many conditions on which the existing studies do not completely agree. These factors include, among others, level of economic development, support for research and development by the host country and importantly, microeconomic determinants. In case of the macro or global level, the studies indicated varying effects based on the country's stage of development, R\&D investment or size, similarly to the effects of export activities of foreign firms. According to van Pottelsberghe de la Potterie and Lichtenberg (2001), the inflowing FDIs from countries that make intense investments in research and development do not allow for a productivity growth through technology transfer, if the country itself does not invest in R\&D highly. However, in the case of making investments in a host country that has high investments in research and development the transfer is noticeable (van Pottelsberghe de la Potterie, Lichtenberg, 2001). Spread of technologies from the inflowing FDI is definitely not simple phenomena to be captured, presumably more thoroughly examined by micro level studies.

\section{Other determinants impacting the high - technology exports}

There are several other factors, apart from FDI, mentioned in the literature and described as the ones impacting the export structure. Such variables as: trade openness, education, exchange rates, migration, domestic savings, gross capital formation (Tebaldi, 2011), human resources, R\&D related factors (Sandu, Ciocanel, 2014), infrastructure (Zhang, 2007), can be found in the previous research. Even though the variables presented in the literature vary, they seem to concentrate around the areas of technological development and R\&D, FDI inflows, macroeconomic factors and human resources.

The results indicate positive correlation of high technology exports with trade openness and human capital (Tebaldi, 2011). Infrastructure as a factor explaining growth of advanced exports appears to lead to mixed results, depending on the time frame covered by the model (Zhang, 2007). As it comes to the research and development factors (R\&D spend), these are identified as significant when a remarkable time lag of two years is applied, also the private $R \& D$ spend is recognized as more relevant (Sandu, Ciocanel, 2014). Moreover, the research leads to the conclusion that the increase in the share of the advanced manufacturing of the country results in an increase in the share of the advanced exports. Similar observation is made in reference to the value added generated which correlated with per capita advanced exports (Zhang, 2007). 


\section{Data and variables}

Based on the theoretical framework and previous study, a simple model with macro level variables is estimated. The choice of variables in the model is based on the literature research and identification of factors commonly associated with export development, the model partially utilizes selection of variables applied by Tebaldi (2011). The included variables are: FDI per capita inflows, investment factors such as gross capital formation and gross domestic savings (Tebaldi, 2011), human capital and R\&D related factors, which include $R \& D$ spend, employment in high and medium-high technology intensive sectors and number of researchers per million of population. There are three estimations executed, for different time frames. The time frames are determined on the basis of the variable's data availability.

All of the independent variables are transformed into first-differences percentage changes to allow to control for non-stationarity. Standard stationarity tests (Levin-Lin-Chu and others) have been performed and proved the lack of existence of it in most of the variables before the transformation (at the level).

The expected outcome is positive sign correlation of the dependent variable with the independent variables.

Independent variables used in the model:

- FDI inflows per capita - the data comes from UNCTAD database. The values are expressed in US dollars at current prices. The utilized data range for the variable is $2000-2018$.

- GCF (Gross Capital Formation) as a percentage of GDP - the data comes from World Bank database (World Development Indicators). The utilized data range for the variable is $2000-2018$.

- GDS (Gross Domestic Savings) as a percentage of GDP- the data comes from World Bank database (World Development Indicators). The utilized data range for the variable is $2000-2018$.

- Trade openness - is a ratio of imports and exports of goods and services to GDP. The data is derived from World Bank database (World Development Indicators).

- R\&D spend (gross domestic expenditure on research and development) - the data comes from OECD. The values are expresses in millions 2015 US dollars in constant prices and PPP's. The utilized data range for this variable is 2000 - 2018, noting that 2018 data is temporary (will be most likely adjusted) and some of the values during the time range are based on calculations applying different methodology.

- Number of researchers in R\&D per million - the data comes from World Bank (World Development Indicators). The data is only available until 2017, hence the time range for this variable in the model is $2000-2017$.

- Employment in high and medium-high technology manufacturing sectors - the data comes from Eurostat and is available only since 2008. Therefore, the utilized time range is 2008-2018. The variable is captured as a ratio of the employees in the above-mentioned sectors to the total employment.

Dependent variable is export of high and medium-high R\&D intensive activities (values in US dollars), reported and classified by OECD. The groups of products that belong to high and medium high technology are: pharmaceutical products, electronic products, computers, optical products, aircraft, spacecraft and associated machinery (categories in high R\&D intensive manufacturing), chemicals, weapons, ammunition, machinery and equipment, electrical equipment, motor vehicles, trailers, transport and railroad equipment, military flying vehicles, medical equipment/ instruments (categories in medium-high R\&D intensive manufacturing) (OECD, 2020). The reason for adding the medium-high technology goods into the model is the fact, that according to OECD classification, only three groups of manufactured products may be classified under high 
$R \& D$ intensive. Therefore, adding medium-high group of products extends the group and makes the research more meaningful. Also, in the literature, export advancement has been investigated using both high and even medium technology products (Zhang, 2007).

Table 1 below presents the data for the descriptive statistics for the both variables at the level, before transformation and for the percentage changes of the variables included in the regression.

\begin{tabular}{|c|c|c|c|c|c|}
\hline Variable & Mean & Median & SD & Min & Max \\
\hline High and medium - high industry exports (mln USD) & 32302 & 15183 & 34531 & 256 & 134100 \\
\hline FDI inflow per capita (as \% of GDP) & 442,6 & 378,2 & 409,9 & -1512 & 2065 \\
\hline Gross Capital Formation (as \% of GDP) & 25,14 & 24,66 & 5,024 & 12,37 & 41,45 \\
\hline Gross Domestic Savings (as a \% of GDP) & 24,53 & 24,96 & 5,109 & 10,69 & 34,52 \\
\hline Trade Openness (imports and exports as \% of GDP) & 127,4 & 127,5 & 30,06 & 58,08 & 190,2 \\
\hline$R \& D$ spend & 2180 & 956,8 & 2457 & 122,5 & 14067 \\
\hline Number of researchers per million & 2392 & 2323 & 745,8 & 1346 & 4476 \\
\hline Employment in high and medium-high tech & 6,395 & 6,850 & 3,485 & 1,300 & 11,50 \\
\hline$\% \Delta$ High and medium - high industry exports & 13,99 & 13,78 & 17,86 & $-36,50$ & 73,28 \\
\hline$\% \Delta \mathrm{FDI}$ inflow per capita & $-210,1$ & $-0,7917$ & 2528 & -29190 & 2985 \\
\hline$\% \Delta$ Gross Capital Formation & 0,1367 & 0,4745 & 11,72 & $-55,64$ & 46,34 \\
\hline$\% \Delta$ Gross Domestic Savings & 1,656 & 1,603 & 8,419 & $-34,47$ & 50,56 \\
\hline$\% \Delta$ Trade Openness & 2,573 & 1,891 & 7,097 & $-16,12$ & 25,48 \\
\hline$\% \Delta \mathrm{R} \& \mathrm{D}$ spend & 7,084 & 6,965 & 13,02 & $-33,31$ & 56,73 \\
\hline$\% \Delta$ Number of researchers per million & 3,632 & 3,816 & 7,662 & $-21,00$ & 48,01 \\
\hline$\% \Delta$ Employment in high and medium-high tech & 0,8783 & 1,539 & 7,949 & $-26,32$ & 25,71 \\
\hline
\end{tabular}

Table 1

Descriptive statistics for the variables

\section{Method}

The model is estimated using ordinary least squares (OLS) regression method. Panel data for eight Central - Eastern European economies, members of the European Union since 2004, is used. OLS regression (instead of fixed or random effects models) has been determined as appropriate by adequate tests performed. Moreover, the fact the percentage changes of the first differences of the variables are applied, supports the choice of the OLS model.

\section{Presentation of the results}

The table 2 below presents the results of the estimations, the coefficients with their significance and the standard errors. Additionally, the results for the heteroskedasticity tests (Wald) together with the R-squared values for the models are included in the table. Even though time frame is short, tests for serial correlation (Wooldridge) has been conducted. The results are not presented in the table, but it has proven no first-order correlation in all three models. 
Table 2

Presentation of the study results
Dependent variable: Exports from industries of high and medium - high R\&D intensive activities, USD mln (\% $\Delta$ )

Panel of 8 countries: Czech Republic, Estonia, Hungary, Latvia, Lithuania, Poland, Slovakia, Slovenia

\begin{tabular}{|c|c|c|c|}
\hline Variable & (1) $2000-2018$ OLS & (2) 2000-2017 OLS & (3) 2008-2018 OLS \\
\hline FDI inflow per capita $(\% \Delta)$ & $\begin{array}{l}0,0010^{\star *} \\
(0,0005)\end{array}$ & $\begin{array}{l}0,0010^{*} \\
(0,0005)\end{array}$ & $\begin{array}{c}0,0005 \\
(0,0003)\end{array}$ \\
\hline Gross Capital Formation $(\% \Delta)$ & $\begin{array}{l}0,2450 \\
(0,1652)\end{array}$ & $\begin{array}{l}0,3170^{*} \\
(0,1688)\end{array}$ & $\begin{array}{l}0,3649^{* *} \\
(0,1504)\end{array}$ \\
\hline Gross Domestic Savings $(\% \Delta)$ & $\begin{array}{l}0,3713^{*} \\
(0,2225)\end{array}$ & $\begin{array}{c}0,3378 \\
(0,2298)\end{array}$ & $\begin{array}{l}0,0518 \\
(0,2166)\end{array}$ \\
\hline Trade Openness $(\% \Delta)$ & $\begin{array}{c}0,7356^{* * *} \\
(0,2123)\end{array}$ & $\begin{array}{l}0,7553^{* * *} \\
(0,2196)\end{array}$ & $\begin{array}{l}1,0046^{* * *} \\
(0,1879)\end{array}$ \\
\hline R\&D spend $(\% \Delta)$ & $\begin{array}{c}0,1573 \\
(0,1062)\end{array}$ & & \\
\hline $\begin{array}{l}\text { Number of researchers in R\&D per million } \\
(\% \Delta)\end{array}$ & & $\begin{array}{l}0,2139 \\
(0,1762)\end{array}$ & \\
\hline $\begin{array}{l}\text { Employment in high and medium-high } \\
\text { tech }(\% \Delta)\end{array}$ & & & $\begin{array}{c}0,1777 \\
(0,1438)\end{array}$ \\
\hline Constant & $\begin{array}{c}10,5534^{* * *} \\
(1,5382)\end{array}$ & $\begin{array}{c}10,8702^{* * *} \\
(1,5931)\end{array}$ & $\begin{array}{c}3,5575^{* * *} \\
(1,2525)\end{array}$ \\
\hline Number of observations & 144 & 136 & 80 \\
\hline Wald test & $\rho=0,1748$ & $\rho=0,2492$ & $\rho=0,0857$ \\
\hline R-squared & 0,3165 & 0,3167 & 0,6172 \\
\hline Adjusted R-squared & 0,2917 & 0,2905 & 0,5913 \\
\hline
\end{tabular}

Legend: $p<0.1^{*} ; p<0.05^{* *} ; p<0.01^{* * *}$

\section{Interpretation of the results}

All three models indicate strong positive correlation between the growth rate of high and medium-high exports development and the growth rate of trade openness. The coefficient for the trade openness is highest among all of the statistically significant variables. Other variables' significance and their coefficient values differ between the models. Even though FDI inflows per capita is significant and positively correlated in two of the models, the coefficient value is low for the variable. Both GCF and GDS which are investment indicators display similar levels of coefficients and are positively correlated with export development. None of the research and development, education and employment related factors is identified in the estimations as significant. Presumably, a significant time lag would have to be added to the regression model in order to observe these effects or a division between private and public spend would have to be made, as it is stated in the literature (Sandu, Ciocanel, 2014). The results are partially consistent with Tebaldi findings (2011), where trade openness and FDI inflow have been also identified as significant positively correlated factor. The results differ in terms of GDS and GFC impact, as in 
Tebaldi's research these are identified as not significant. In the results, the author indicates that in his research group of over 90 countries within 28 years, the export advancement is human capital intensive, not capital intensive (Tebaldi, 2011). This is contrary to the findings of this paper, which indicates significant capital involvement in the export advancement in Central-Eastern Europe. Possibly, the shorter timeframe for the research and different specification of the countries chosen to the panel cause the difference in the results obtained.

The research uses panel data regression estimation to study the effects of FDI inflows together with other variables on the growth of exports of high and medium-high R\&D intensive manufactured products. FDI matters for explaining the phenomena, but on a limited level. The obtained results suggest positive and significant impact of FDI inflows, however, compared to other significant variables, quite low in value. As the countries from the region are still receiving mixed type of FDI (some may be only internal market-oriented), the overall effect of FDI may show blurry picture. What is more, a 2008 study on the investment development path of the economies from the region indicates that none of the examined economies is at stage three of their investment development path (Boudier-Bensebaa, 2008), which would mean moving towards more advanced inflowing investment structure. An in-depth sectoral study for the Central-Eastern European economies could indicate whether the FDI inflows are directed towards R\&D intense sectors. There are other variables, used in the model, that demonstrate higher values of the coefficient and therefore, stronger impact on high technology exports growth. Trade openness is a variable that not only indicates the level of country's engagement in foreign trade transactions, but also reflects its overall economic performance. It can be concluded, that in the Central-Eastern European region companies from the countries participating in internationalization through trade patterns significantly develop the exports structure. Trade appears to be the factor which allows for the learning and technology spillover to the domestic companies. Also, notably in the short period, gross capital formation is a factor that positively correlates with trade development. This may indicate that the high-tech export activities require some capital intensity in the region in the short term. The panel is based on relatively short period of time which may be the main reason of why the impact of $R \& D$ is not visible in the results as significant. Most likely, a longer time frame together with some significant time lags would have to be applied in order to better examine the relation. To conclude, it may be stated that this simple panel regression model compares relevant macro level factors and presents an overall suggestion of which factors matter for the export advancement. It also sheds some light on the relevance of FDI among other variables, which is positively significant but not strong.

Banga R. (2006). The export-diversifying impact of Japanese and US foreign direct investments in the Indian manufacturing sector, Journal of International Business Studies, 37, pp. 558-568. Retrieved De-cember 10th, 2019, from: https://www. researchgate.net/publication/5223213_The_export-diversify-ing_impact_of_Japanese_and_ US_foreign_direct_investments_in_the_Indian_ manufacturing_sector https://doi.org/10.1057/ palgrave.jibs. 8400207
Boudier-Bensebaa, F. (2008). FDI-assisted development in the light of the investment development path paradigm: Evidence from Central and Eastern European countries, Transnational Corporation, 17(1), pp. 37-67. Retrieved June 2nd, 2020, from: http://citeseerx.ist.psu.edu/viewdoc/download?doi=10.1.1.504.387\&rep=rep 1 \&type=pdf

Eurostat (2020). Employment in high- and medium-high technology manufacturing sectors and knowledge-intensive service sectors. Retrieved May 
27th, 2020, from: https://ec.europa.eu/eurostat/databrowser/view/tsc00011/default/table?lang=en

Harding T., Smarzynska Javorcik B. (2011). FDI and export upgrading, University of Oxford Department of Economics Discussion Paper Series, (No. 526). Retrieved December 10th, 2019, from: https://www. economics.ox.ac.uk/materials/papers/4836/paper526.pdf

Iwamoto M., Nabeshima K. (2012). Can FDI Promote Export Diversification and Sophistication of Host Countries? Dynamic Panel System GMM Analysis, IDE Discussion Paper, (No. 347). Retrieved Decem-ber 10th, 2019, from: https://ir.ide.go.jp/index. php?action=pages_view_main\&active_action=repository_action_common_download\&item_ $i d=37827 \& i t e m \_n o=1 \&$ attribute_id=22\&file_ no=1\&page_id=26\&block_id=95

Keller W. (2004). International Technology Diffusion, Journal of Economic Literature, XLII (September 2004), pp. 752-782. Retrieved December 10th, 2019, from: http://spot.colorado.edu/ kellerw/ITD. pdf https://doi.org/10.1257/0022051042177685

OECD (2020). Bilateral Trade in Goods by Industry and End-use. Retrieved May 21st May, from: https:// stats. oecd.org/index.aspx?queryid $=64755$

OECD (2020). Gross domestic expenditure on R\&D by sector of performance and source of funds. Retrieved May 26th, 2020, from: https://stats.oecd.org/ Index.aspx?DataSetCode=GERD_SOF

Sandu S., Ciocanel B. (2014). Impact of R\&D and Innovation on high - tech export, Emerging Markets Queries in Finance and Business, 15, pp. 80-90. Retrieved June 1st, 2020, from: https://www.researchgate.net/publication/277583299_Impact_of_RD_ and_Innovation_on_High-tech_Export https://doi. org/10.1016/S2212-5671(14)00450-X

Smarzynska Javorcik B. (2004). Does Foreign Direct Investment Increase the Productivity of Domestic Firms? In Search of Spillovers Through Backward Linkages. American Economic Review, American Eco-nomic Association, 94(3), pp. 605-627. Retrieved December 10th, 2019, from: http://users. ox.ac.uk/ econ0247/JavorcikAER.pdf https://doi. org/10.1257/0002828041464605

Tebaldi E. (2011). The Determinants of High-Technology Exports: A Panel Data Analysis, Atlantic Eco-nomic Journal, 39, pp. 343-353. Retrieved June 2nd, 2020, from: https://link.springer.com/article/10.1007/s11293-011-9288-9

UNCTAD Stat (2019). Foreign direct investment inward and outward flows and stock, annual. Retrieved May 23rd, 2020, from: https://unctadstat. unctad.org/wds/TableViewer/tableView.aspx

Van Assche A., Gangnes B. (2007). Electronic Production Upgrading: Is China Exceptional?, Applied Economic Letters, 17(5), pp. 477-482. Retrieved June 2nd, 2020, from: https://core. ac.uk/download/pdf/7163329.pdf https://doi. org/10.1080/13504850701765101

van Pottelsberghe de la Potterie B., Lichtenberg F. (2001). Does foreign direct investment transfer tech-nology across borders? The Review of Economics and Statistics, 83(3), pp. 490-397. Retrieved December 10th, 2019, from: http://www.rcmewhu.com/upload/file/2015 0527/20150527094247_3165.pdf https://doi. org/10.1162/00346530152480135

World Bank (2020). World Development Indicators, Gross capital formation (\% of GDP). Retrieved May 27th, 2020, from: https://databank.worldbank. org/reports. aspx? source=2\&series=NE.GDI. TOTL.ZS\&country=

World Bank (2020). World Development Indicators, Gross domestic savings (\% of GDP). Retrieved May 23rd, 2020, from: https://databank.worldbank. org $/$ reports.aspx? source=2\&series=NY.GDS.TOTL. ZS\&country=

World Bank (2020). World Development Indicators, Trade (\% of GDP). Retrieved May 23rd, 2020, from: https://databank.worldbank.org/ reports.aspx? source $=2 \&$ series=NE.TRD.GNFS. ZS\&country=

World Bank (2020). World Development Indicators, Researchers in R\&D (per million people). Retrieved May 21st, 2020, from: https://databank.worldbank. org $/$ reports. aspx? source=2\&series=SP.POP.SCIE. RD.P6\&country=

Xu B. (2010). The sophistication of exports: Is China special?, China Economic Review, 21, pp. 482493. Retrieved June 2nd, 2020, from: https://cn. ceibs.edu/sites/default/files/faculty-profiles/cv/ xubin/chinaspecial.pdf https://doi.org/10.1016/j. chieco.2010.04.005 
Zhang K. H. (2007). Determinants of complex exports: evidence from cross-country data for 19851998. Economia Internazionale / International Economics, 60(1), pp. 111-122. Retrieved June 2nd, 2020, from: http://www.iei1946.it/RePEc/ccg/ ZHANG\%20111_122.pdf
Zhu S., Fu X. (2013). Drivers of Export Upgrading. World Development, 51, pp. 221-233. Retrieved De-cember 10th, 2019, from: https://core. ac.uk/download/pdf/82121375.pdf https://doi. org/10.1016/j.worlddev.2013.05.017

\section{GORNIAK AGATA MARIA}

\section{PhD Student}

Kozminski University

Fields of interests

International economics, international business.

\section{Address}

Jagiellonska 57

03-301 Warsaw, Poland

Phone: +48 667378040

E-mail: agatamariagorniak@gmail.com
About the author 